NASA Technical Memorandum 81722

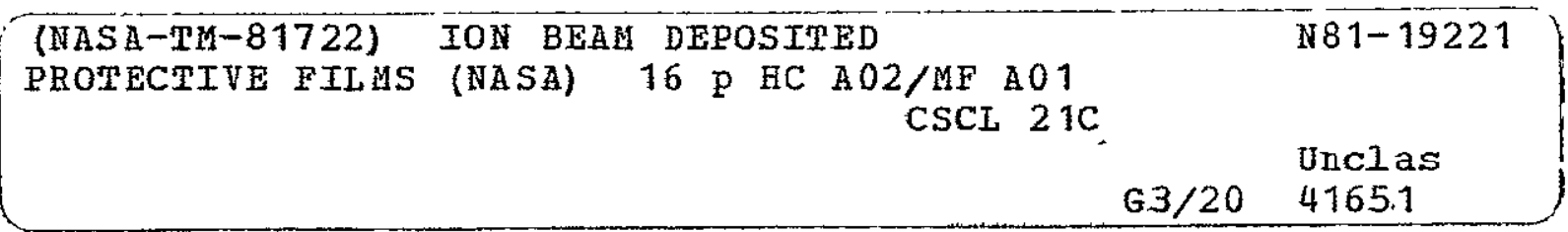

\title{
Ion Beam Deposited Protective Films
}

Michael J. Mirtich

Lewis Research Center

Cleveland, Ohio

Prepared for the

Fifteenth International Electric Propulsion Conference cosponsored by the American Institute of Aeronautics and Astronautics, the Japan Society for Aeronautical and Space Sciences, and Deutsche Gesselschaft fur Luft- und Raumfahrt Las Vegas, Nevada, April 21-23, 1981 


\begin{tabular}{|c|c|c|c|}
\hline $\begin{array}{l}\text { 1. Report No. } \\
\text { NASA TM-81722 }\end{array}$ & 2. Government Accersion No. & \multicolumn{2}{|c|}{ 3. Rociplent's Catalog No. } \\
\hline \multirow{2}{*}{\multicolumn{2}{|c|}{$\begin{array}{l}\text { 4. Title and Subtitio } \\
\text { ION BEAM DEPOSITED PROTECTIVE FILMS }\end{array}$}} & \multicolumn{2}{|l|}{ 5. Report Date } \\
\hline & & \multicolumn{2}{|c|}{$\begin{array}{l}\text { 6. Porforming Organization Code } \\
506-55-32\end{array}$} \\
\hline \multirow{2}{*}{\multicolumn{2}{|c|}{$\begin{array}{l}\text { 7. Author(s) } \\
\text { Michael J. Mirtich }\end{array}$}} & \multicolumn{2}{|c|}{$\begin{array}{l}\text { 8. Performing Organlzation Report No. } \\
\text { E-759 }\end{array}$} \\
\hline & & \multicolumn{2}{|l|}{ 10. Work Unit No. } \\
\hline \multirow{2}{*}{\multicolumn{2}{|c|}{$\begin{array}{l}\text { 9. Performing Organization Name and Addres } \\
\text { National Aeronautics and Space Administration } \\
\text { Lewis Research Center } \\
\text { Cleveland, Ohio } 44135\end{array}$}} & \multicolumn{2}{|c|}{ 11. Contract or Grant No. } \\
\hline & & \multirow{2}{*}{\multicolumn{2}{|c|}{$\begin{array}{l}\text { 13. Type of Report and Period Covered } \\
\text { Technical Memorandum }\end{array}$}} \\
\hline \multirow{2}{*}{\multicolumn{2}{|c|}{$\begin{array}{l}\text { 12. Sponsoring Agency Name and Address } \\
\text { National Aeronautics and Space Administration } \\
\text { Washington, D. C. } 20546\end{array}$}} & & \\
\hline & & \multicolumn{2}{|c|}{ 14. Sponsoring Agency Code } \\
\hline \multicolumn{4}{|c|}{$\begin{array}{l}\text { 15. Supplementary Notes } \\
\text { Prepared for the Fifteenth International Electric Propulsion Conference cosponsored by the American } \\
\text { Institute of Aeronautics and Astronautics, the Japan Society for Aeronautical and Space Sciences, and } \\
\text { Deutsche Gesselschaft fur Luft- und Raumfahrt, Las Vegas, Nevada, April 21-23, 1981. }\end{array}$} \\
\hline \multicolumn{4}{|c|}{$\begin{array}{l}\text { 16. Abstract } \\
\text { Single or dual'ion beam sources were used to deposit thin films for three different applications. } \\
\text { Metal and metal oxide fllms were evaluated as protective coatings for die materials. Film adher- } \\
\text { ence was measured and the most promising fllms were then tested under environments similar to } \\
\text { operating conditions. It was shown that some materials do protect dle materlal (H-13 steel) and } \\
\text { do reduce thermal fatigue. Diamondlike films have many useful applications. A sertes of exper- } \\
\text { iments were conducted to define and optimize new approaches to the manufacture of such films. } \\
\text { A dual beam system using argon and methane gases was developed to generate these films. The } \\
\text { results of initial measurements which determine the quality of the films are reported. The fiber. } \\
\text { glass beam shield incorporated in the 8-cm diameter mercury ion thruster to be used aboard a } \\
\text { space flight experiment was coated with molybdenum to insure proper electrical and thermal } \\
\text { properties. During the evolution of these programs, deposition parameters and fixturing tech- } \\
\text { niques were developed and are also presented. }\end{array}$} \\
\hline $\begin{array}{l}\text { 17. Key Words (Suggested by } \\
\text { Sputtering } \\
\text { Ion sources } \\
\text { Diamond-like films } \\
\text { Ion beam deposited }\end{array}$ & $\begin{array}{l}\text { 18. Distribu } \\
\text { Uncl } \\
\text { STAI }\end{array}$ & unlimited & \\
\hline $\begin{array}{r}\text { 19. Security Classif. lof this repor } \\
\text { Unclassified }\end{array}$ & $\begin{array}{l}\text { 20. Security Classif. (of this page) } \\
\text { Unclassified }\end{array}$ & 21. No. of Pages & 22 Price* \\
\hline
\end{tabular}




\section{ION BEAM DEPOSITED PROTECTIVE FILMS}

Michael J. Mirtich

National Aeronautics and Space Administratior

Lew s Research Center

Cleveland, Ohro 44135

\section{Abstract}

Single or dual ion beam sources were used to deposit thin films for three different applications. Metal and metal oxide films were evaluated as protective coatings for die materials. Film -adherence was measured and the most promising films were then tested under environments similar to operating conditions. It was shown that some materials do protect die material ( $\mathrm{H}-13$ steel) and do reduce thermal fatigue. Diamondlike films have many useful applications. A series of experiments were conducted to define and optimuze new approaches to the manufacture of such films. A dual beam system using argon and methane gases was developed to generate these films. The results of initial measurements which determine the quality of the films are reported. The fiber glass beam shield incorporated in the 8-cm diameter mercury ion thruster to be used aboard a space flight experiment was coated with molybdenum to insure proper electrical and thermal properties. During the evolution of these programs, deposition parameters and fixturing techniques were developed and are also presented.

\section{Introduction}

An ion beam source has a unique capability of sputter depositing adherent thin films on rather complex geometric surfaces. Ion beam deposition allows greater isolation of the substrate from the ion generation process than is found in most sputter deposition systems (i.e., radio frequency ( $r f$ ), ion plating, diode sputtering). 1 This enables control 'over the substrate temperature, gas pressure, angle of deposition, and the type of particle bombardment of the growing film, as well as independent control over the ion bean current and energy. The low pressures associated with the ion beam process offers cleaning and deposition capabilities that are conducive to highly adherent thin films.

An Ion Beam Applications Program was undertaken at N.A.S.A. Lewis Research Center to transfer ion beam developed technology to industry and use the capabilities of ion source technology for other aerospace applications. The results of these programs that involved deposition of thin adherent films are presented. One program, developed in cooperation with the Die Cast Research Foundation, was to improve die lifetime by sputter depositing coatings on a die surface using an ron bean source. A second program was to evaluate the use of an ion source to generate films having diamond-like properties. A third program involved the coating of the $8 \mathrm{~cm}$ diameter, electron-bombardment mercury jon thruster fiber glass beam shield with a metal coating that will insure appropriate electrical and optical thermal properties. This paper presents the techniques and results of these coating applications that used either single or dual beam ion sources.
Sputtered Protective Coatings for Die

\section{Casting Dies}

A program was developed at NASA Lewis Research Center in cooperation with the Die Casting Research Foundation to improve die lifetime by sputter depositing coatings on a die surface using ion thrusters as ion beam sputtering sources. This protective coating would inhibit thermal fatigue cracking called heat checking in the die - that is, the thermal stresses associated with the aluminum casting process. The program consisted of three overlapping phases: (1) determination of the adherence of films as a function of thickness, (2) thermal fatigue testing of selected films in a die simulation system, (3) deposition of a film on a die to be used in casting production. In the first phase coatings of various candidate metal and metal oxides were sputter deposited on flat surfaces made of $\mathrm{H}-13$ steel (die material) for a preliminary evaluation of the adherence of various thickness films. 2 . During this phase, the sputter technique, sputter rate, deposition energy leve T, and maximum thickness prior to spalling were determined for each candidate coating material.

A $30-\mathrm{cm}$ diameter argon ion beam source ${ }^{3}$ with its ion optics masked down to an ion beam diameter of $10 \mathrm{~cm}$, was used for the sputter deposition of the metal and metal oxide materials. The ion source, developed from electric propulsion technology, uses argon gas in a hollow cathode in the main discharge chamber as well as for the neutralizer. The jon source is capable of operation at ion beam energy levels between 100 and $1500 \mathrm{eV}$. For these studies the source was operated so as to produce a $1000 \mathrm{eV}$ ion beam.

The vacuum facility, $1.5 \mathrm{~m}$ in diameter and $7.3 \mathrm{~m}$ long, was sufficiently large to minimize film contamination from back sputtered facility material. - To further prevent contamination, a liquid nitrogen cooled baffle was used in the vacuum tank during all the depositions described in this paper. While the ion source was operating, the pressure in the region of the experiment is about $3 \times 10^{-4}$ torr $\left(3.9 \times 10^{-2} \mathrm{~Pa}\right)$. This pressure was maintained for most of the depositions. The partial pressure of $\mathrm{N}_{2}$ or ajr in processing nitride or oxide compounds was intentionally increased to about $1 \times 10^{-3}$ torr. It should be noted that at $10^{-3}$ torr about 50 percent of the ions become neutralized through charge exchange 4 and half of the sputtering is done by $1000 \mathrm{eV}$ neu- , trals rather than ions.

To assure good adherence of the film to the $\mathrm{H}-13$ steel substrates, the substrates were cleaned prior to insertion into the vacuum facility and also sputter cleaned by the jon beam for $1 / 2$ hour at an ion beam energy of $1000 \mathrm{eV}$ and a current density of $2 \mathrm{~mA} / \mathrm{cm}^{2}$. The cleaning procedure prior to insertion in the vacuum facility included cleaning the disks with a 2-percent Liquinox $(B)$ soap solution, 
rinsing in distilled water, and drying with nitrogen gas. This procedure was performed three times on each disk.

Because of the sample size $(2.54 \mathrm{~cm}$ diameter, $1.5 \mathrm{~mm}$ thick) and flat geometry, the relatively simple fixturing shown in Fig. 1 was used to mount and hold the target and substrates (disks). The disks were mounted on a push-pull rod that could be retracted through a vacuum chamber gate valve. During the sputter cleaning of the substrate, the target was located in a stored position. During deposition the target and substrate surfaces are $19 \mathrm{~cm}$ apart and normal to each other and the target was at a $45^{\circ}$ with respect to the incident ion beam. The distance from the jon source to the target was $19 \mathrm{~cm}$.

The deposition rate of target material at the location of the substrate was measured by placing a piece of fused silica glass which was masked to allow a step to form during deposition. A profilometer (Alpha-Step) was used to measure the thickness of the film and hence a deposition rate could be derived.

Presented in Table I are the deposition rates at the substrate location for various target materials. The ion bean was larger in diameter than the area of the target $(15 \mathrm{~cm})$ and totally filled the target material. The deposition rates are presented in Table I for a current density at the target of $1 \mathrm{~mA} / \mathrm{cm}^{2}$ and an ion energy of $1000 \mathrm{eV}$.

Adherence measurements, of the $f i 7 \mathrm{~m}$ to the substrate, were made using a Sebastian Series Coating Adherence Tester $(B)$. Measurements are made by first baking an epoxy coated bonding stud $10.127 \mathrm{~cm}$ long by $0.16 \mathrm{~cm}$ in diam) to the deposited film surface at $125^{\circ} \mathrm{C}$ for 2 hours in an oven. This elevated temperature allows for a themal cure of the epoxy coated stud to the film. After the stud is bonded to the film, the test stud is inserted into the instrument and a load is applied nomal to the surface at a predetermined rate until failure of the bond ensues. This break in the bond is recorded in $1 \mathrm{~b} / \mathrm{in}^{2}$, and is considered a measure of the adherence, if the break occurs at the film-substrate interface. The maximum adherence from this test is the strength of the epoxy bond (approx. 6500$\left.9000 \mathrm{lb} / \mathrm{in}^{2}\right) \cdot(44-62 \mathrm{MPa})$. For most of the fjims tested in these experiments, the bond strength of the film to the substrate exceeded the bond strength of the stud (epoxy) to the film. The location of the break in the bond was determined by using an optical microscope or a scanning electron microscope.

Presented in Table II are the adherence of various thickness ion beam deposited metal and metal oxide films on $\mathrm{H}-13$ steel. The adherence measurements are the average of five measurements on each sample. Some of the depositions were done at NASA Lewis Research Center and some at Commonwealth Scientific Corporation. Although the two facilities used different size ion sources, the experimental procedures were the same. The use of different facilities and sources did not seem to affect the results, for Mo deposited at both Lewis Research Center and Commonwealth Scientific Corporation exhibit the same strong adherence for films $<4 \mathrm{~mm}$ thick. The symbol * used in Table II ind icates a break in the bond at the epoxy-film interface, meaning the film-substrate bond strength was greater than the value indicated in the table. For all the metallic films $\leq 4 \mu \mathrm{m}$, the bond strengths between the film and the substrate were greater than the epoxyfilm bond. The only exception was $\mathrm{B}_{4} \mathrm{C}$, which formed a poor bond on $\mathrm{H}-13$ for all thicknesses. Films of $\mathrm{Au}, \mathrm{Ag}$, Mo (deposited at LeRC) and Ta5Si3, $8 \mu \mathrm{m}$ thick, as well as $1-\mu \mathrm{m}$ coating of the same material, exhibit bond strengths greater than the epoxy bond. It was also found that the adherence of the films were independent of the substrate surface finish (16 or $32 \mu i n$. finish).

Film bond strengths were also measured on some materials that were deposited on $\mathrm{H}-13^{\circ}$ using other deposition systems. Shown in Fig. $2^{2}$ is a plot of the film adherence as a function of thickness for $\mathrm{Mo}, \mathrm{Cr}, \mathrm{Ni}$, and $\mathrm{ZrO} 2$ using ion beam, radio frequency ( $r f)$, or ion plating deposition systems. Ion plating of Mo was performed by Hohlman plating. The open symbols indicate that the bond broke at the epoxy-film interface and the closed symbols, a break at the film-substrate interface. For $\mathrm{Mo}_{0} \mathrm{ZrO}_{2}$, and $\mathrm{Cr}(\leq 3 \mu \mathrm{m}$ thick) deposited with either an ion bean or $r f$ sputter system, the adherence of the films were stronger than the epoxy bond strength. $\mathrm{Ni}$ film adherence on $\mathrm{H}-13$ steel was greater than $8000 \mathrm{lb} / \mathrm{in}^{2}(55 \mathrm{MPa})$ when an ion beam source was used for $f i l m$ deposition. Adherence of $r f$ sputter deposited films ranged from about 7000 to $280 \mathrm{lb} / \mathrm{in}^{2}$ (48 to $1.9 \mathrm{MPa}$ ) depending on film thickness. The use of an ion beam or rf source appears to give better Mo film adherence than from deposition using a commercial ion plating system.

In the second phase of this program, the most adherent candidate coatings were sputter deposited on a thermal fatigue test specimen ${ }^{5}$ similar to the one shown in Fig. 3. This coated test specimen was then repeatedly immersed in molten aluminum and then cooled by a water spray for 15,000 cycles, to simulate the thermal fatigue environment of a production die casting die. The thermal fatigue specimen $(5 \times 5 \times 16 \mathrm{~cm})$ has sharp corners $(0.025 \mathrm{~cm}$ radius) to initiate thermal cracks within the 15,000 cycle test. At the corners of the specimen the temperature fluctuations and resulting thermal stresses are maximized and thus the site of crack initiation and propagation. In the ion beam-coating process each of three corners (see Fig. 3) was coated with a different material using some rather unique fixturing to manipulate the specimen. Shown in Fig. 4 is an overview of the bell jar, flange-ion source, target, test specimen, and fixturing. The conf iguration shows the specimen in a stored position, while the target was located at the position where it was cleaned by the ion source to remove cont aminants from its surface. In Fig. 5, by use of the pushpull system, one corner of the thermal fatigue test specimen was moved into position to be cleaned by the ion source. In this position the target $(15 \mathrm{~cm}$ diameter disk) was in a stored position. As in the first phase of this program the specimen were cleaned for $1 / 2$ hour at an jon beam energy of $1000 \mathrm{eV}$ and a current density of $2 \mathrm{~mA} / \mathrm{cm}^{2}$. The other three corners of the specimen are protected from the beam by a shield made of spring steel that was slipped onto the specimen prior to insertion into the vacuum facility. Shown in Fig. 6 is the relative position of the specimen and target during deposition. To place the specimen in this position from that shown in Fig. 5 it was rotated $180^{\circ}$ in the horizontal plane and then rotated $45^{\circ}$ in the vertical plane by a push rod (shown at the top of the specimen in Fig. 5) that hits the bell jar wall during retraction from the cleaning position. 
One corner of each specimen was left uncoated and served as a reference surface for comparison with the other coatings during the thermal fatigue tests. Presented in Table III are the results of exposing eight thermal fatigue specimen to molten aluminum and cold water for 15,000 cycles. The coatings were all 1 micron thick except where specified. Two parameters are used to characterize the degree of thermal fatigue cracking. The largest crack on each edge was recorded and referred as "The Maximum Crack Length." The term, ind2, is referred to as "The Cracked Area." The length of each crack segregated into groups between selected micron length groups was multiplied by the. number of cracks, $n$ within that crack length group. "These $n d^{2}$ terms are then added to provide a $\Sigma$ nd 2 value for each edge. The results of this study show that some materials, Mo, $W$, and $P t$, reduce thermal fatigue (i.e., the maximum crack length and ind? are less than the uncoated corner. However, some other coatings, that $1 \mathrm{~s}, \mathrm{Co}, \mathrm{Ag}$, and $\mathrm{T}_{5} \mathrm{Si}_{3}$ seem to enhance the maximum crack length and the total number of cracks. Shown in Fig. 7 is a transverse view of a $W$ coated specimen. This metallograph clearly shows the coating intact on the $\mathrm{H}-13$ steel even after 15,000 exposure cycles to molten alumunum and cold water. This may imply other potential protective uses of the films such as wear, oxidation, and sulfidation inhibition.

In the last phase of this program one half of a dual cavity die will be coated with the film and techniques found to best protect the test specimen from thermal fatigue cracking. This die, coated with a commercial ion source, will then be used for production of aluminum castings. At periodic intervals of casting production an evaluation will be made of both the coated and uncoated portions of the die. This part of the program has just started and the results are not available for this publication.

\section{Diamond-like Carbon Films}

As part of the Ion Beam Applications sections efforts to utilize the nonpropulsive applications of electric propulsion technology, an effort was init]ated to evaluate the capability of using jon beam sputter sources to deposit diamond-like films. Films exhibiting diamond-like properties have numerous applications as scratch resistant coatings for polymers, weather resistant coatings, and biocompatable coatings on biomedical implants. The properties of the films include extreme mechanical hardness, chemical inertness, high dielectric strength, optical transparency, large band gap, high electrical resistivity, and high thermal conductivity.

There have been many publications recently reporting efforts to.produce carbon thin films with diamond-like properties. A variety of plasma and. jon beam techniques have been employed to generate the carbon films. The films can be made by of plasma decomposition of a hydrocarbon gas, 6,7 or other alkanes, 8 by low energy carbon ion beam deposition, 9 or by ion plating and duai beam techniques. 10 Weisanantel, et 21.10 refer to these films as i-carbon ( $j-C$ ) implying that some type of ion bombardment or ion beam is involved in the film. preparation. At NASA Lewis.Research Center films have been produced by direct carbon ion bean deposition using methane $\left(\mathrm{CH}_{4}\right)$ in either single or dual ion beam sources.
The 30-cm ion source with its optics masked to $10 \mathrm{~cm}$, used to sputter deposit protective coatings on $\mathrm{H}-13$ steel, was only slightly modified to directly deposit i-carbon films. Argon was used in the cathode to establish a discharge and then $\mathrm{CH}_{4}$ was intróduced into the discharge chamber as the main "flow. Introduction of $\mathrm{CH}_{4}$ into the discharge chamber and keeping all the other thruster parameters constant caused an increase in the discharge voltage $\left(\Delta V_{I}\right)$ typically from an initial 35 volts to approximately 50 volts. For most of the depositions the ratio of the number of $\mathrm{CH}_{4}$ molecules to argon atoms was 28 percent. This ratio was found to be ideal for generating a film. If the $\mathrm{CH}_{4} / \mathrm{Ar}$ ratio was too large the discharge extinguished. No films were observed for too low a $\mathrm{CH}_{4} / \mathrm{Ar}$ ratio since this condition did not allow a net deposition of $\mathrm{C}$ atoms due to the more dominant sputtering effects of the Ar ions. The ideal energy level for deposjtion of $i$-carbon films is between 100 and 150 ev. 8,9 In these experiments the total ion beam energy is the sum of the discharge voltage $\left(\Delta V_{I}\right)$ and the screen grid voltage $\left(V_{I}\right)$, due to the electrical power supply configuration. Therefore for a discharge voltage of about 50 volts the screen grid voltage was approximately 50 volts. At this low $V_{I}$, it was necessary to increase the accelerator voltage $V_{A}$ more negative (typically to -600 volts) to extract a beam.

Shown in Fig. 8 is the ion beam current density in milliamps per square cent imeter $\left(\mathrm{mA} / \mathrm{cm}^{2}\right)$ versus the axial distance measured from the centerline of the dished Mo grids (grid separation using an isomica spacer was $0.55 \mathrm{~mm}$ ). The measurements were taken at net ion energies of 63 and $99 \mathrm{eV}$ using a $0.709 \mathrm{~cm}^{2}$ Mo planar probe biased at -31 volts with respect to facility ground. (The probe data presented has not been corrected for secondary electron emission.) The $\mathrm{CH}_{4} / \mathrm{Ar}$ ratio was 28 percent at an accelerator voltage of -600 volts. With a screen grid voltage $\left(V_{I}\right)$ of only 28 volts and $\Delta V_{I}=34$ volts, it was possible to obtain a current density of $\sim 1 \mathrm{~mA} / \mathrm{cm}^{2}$ at a distance of $2.5 \mathrm{~cm}$ downstrean of the grids. The rapid decrease in current density with distance from the grids, allows latitude in picking the proper substrate location during deposition.

Figure 9 shows the variation in current density, as the total.ion energy $\left(\Delta V_{I}+V_{I}\right)$ is varied. The data was taken on the centerline at"a location 2.5 and $10 \mathrm{~cm}$ downstream of the grids. At $2.5 \mathrm{~cm}$ from the grids, current densities in excess of $1.0 \mathrm{~mA} / \mathrm{cm}^{2}$ can be obtained for total ion energy leve is Tess than $100 \mathrm{eV}$.

Presented in Fig 10 is the beam current density transverse profile at a location $10 \mathrm{~cm}$ downstream of the grid plane for a current of $106 \mathrm{~mA}$ and an jon energy of $234 \mathrm{eV}$. The beam profile is relatively symmetric about the centerline and does not have the peaked beam profile-characteristic of a divergent field Ar ion source operated at $1 \mathrm{keV}^{2}$. This is undoubtedly. due to additional defocusing at the low extraction voltages.

Knowing the current density and the knowledge that a divergent field ion source can be operated at low voltages, it was possible to design an experiment using a single ion source $(30 \mathrm{~cm})$ with $\mathrm{CH} 4 / \mathrm{Ar}$ at $100 \mathrm{eV}$ and a current density of $-0.2 \mathrm{~mA} / \mathrm{cm}^{2}$ and obtain $i$-carbon films. A current density of $0.2 \mathrm{~mA} / \mathrm{cm}^{2}$ was suggested by $S$. Aisenberg' as an upper 
limit current density. Films were deposited on Si 'and quartz at thicknesses up to $6000 . \AA$ and at deposition rates as high as $71 \AA /$ min. The resistance of the films on silicon was measured to be as high. as $10^{10}$ ohms. The index of refraction was measured at 3.2, and the films were transparent., However, results of electron diffraction studies indicate there' is no evidence of crystallinity in these films, deposited using a single ion.source.

Scanning Auger Microscopy (SAM)' was performed on the films under contract ${ }^{11}$ by $\mathrm{J}$ : Angus of Case-Western Reserve University. SAM spectra of a natural diamond is shown in Fig. 11 and can be compared with the SAM spectra for a NASA film in Fig. 12. There is a large carbon peak at $263 \mathrm{eV}$ and a smaller peak presumably Si at $85 \mathrm{eV}$ for the natural diamond and no evidence of other elements are visible in Fig. 11. For the deposited sample in Fig. 12 a small argon signal and a carbon peak only slightly less than that of diamond are observed and no other elements were observed. Hence, the NASA samples, though amorphous, do contain mostly carbon.

Because amorphous films were obtained using a single- ion source it was felt that an addition of energetic gas ions: of higher energy such as argon in proper proportions might supply additional energy to increase the mobiljty of the amorphous atoms. Marinow and Dobrew12 have found that active sites for nucleation are created and the growth and coalescence of the nuclei enhanced due to an increased mobility of the condensing atoms when film structures are bombarded by inert gas beams. With this in mind, a dual beam system, created by adding an 8-cm argon ion source, shown in Fig. 13 was used to generate the next set of $j-c$ arbon films. The $8 \rightarrow \mathrm{cm}$ source, using a filament cathode, was located at a $12^{\circ}$ angle with respect to the $30-\mathrm{cm}$ source and $25 \mathrm{~cm}$ from the substrate. There was no observed interaction between the two sources or the lon beams during operation. With this system a hollow cathode neutralizer ${ }^{3}$ using argon was needed for beam neutralization.

A Mo probe was located $25 \mathrm{~cm}$ from the $8-\mathrm{cm}$. source and $11.4 \mathrm{~cm}$ from the $30-\mathrm{cm}$ source at a $30^{\circ}$ angle with respect to the centerline of the $30-\mathrm{cm}$ source. This was al so the location of the substrates. With only argon in the $30-\mathrm{cm}$ ion source, a discharge voltage of 35 volts and a beam current of $120 \mathrm{~mA}$ the current density at the probe was $1 \mathrm{~mA} / \mathrm{cm}^{2}$. Introducing $\mathrm{CH}_{4}$ into the $30-\mathrm{cm} \mathrm{d} / \mathrm{s}-$ charge chamber, such that the ratio of $\mathrm{CH}_{4} / \mathrm{Ar}$ was 28 percent did not change the current density $\left(1 \mathrm{~mA} / \mathrm{cm}^{2}\right.$ ) recorded by the probe. It was also noted that the current densities of the $8-$ and $30-\mathrm{cm}$ sources at the probe location were additive.

A series of films were deposited on fused silica ( $\mathrm{SiO}_{2}$ ) and $\mathrm{Si}$ using the dual ion beam system. The current density of the 8-cm source at the substrate was $25 \mu \mathrm{A} / \mathrm{cm}^{2}$ and the argon ron energy was varied from 200 to $600 \mathrm{eV}$, while the $30-\mathrm{cm}$ source, using a $\mathrm{CH}_{4} / \mathrm{Ar}$ ratio of .28 percent, had produced a $110 \mathrm{eV}$ ion beam at $0.200 \mathrm{~mA} / \mathrm{cm}^{2}$. It was found that with the $8-\mathrm{cm}$ source at $600 \mathrm{eV}$, net etching and no deposition took'place on the Si and fused silica substrates: Films were generated on the substrate when the $8 . \mathrm{cm}$ ion source was operated at ion energy levels.lower than.550'eV: The films generated with the dual ion beam method also exhibited resistance values of $10^{10}$ ohms and are transparent. The films also do not idissolve in

$\mathrm{HNO}_{3} / \mathrm{H}_{2} \mathrm{SO}_{4}$. These films are in the process of being evaluated for crystallinity, hardness and infrared absorption.

\section{Coating of 8-cm Beam Shield}

A beam shield described in Ref. 13 will be incorporated on an 8-cm diameter, electron-bombardment mercury ion thruster system to be flight tested on the Shuttle-launched Air force Space Test Program P80-1 satellite currently scheduled to be launched. in 1983. The beam shield shown in Fig. 14 assures that all possible ion and neutral particle trajectories from the thruster grid system which diverge by $>45^{\circ}$ from the thruster axis are intercepted to protect solar arrays from deposition or etching. Extended engineering model thruster operation with the flight design beam shield has demonstrated, :that the entire interior surface of the shield is subject to a net deposition of sputtered material during normal thruster operation. The deposited material on the shield is indicated to be nearly all molybdenum (Mo), sputtered from the thrusters grid system. The beam shield made of fiiber. glass has two undesirable characteristics; its: electrical surface conductivity is not uniform -and its therma'l properties are such that may allow it to get too cold during eclipse conditions, even during thruster"operation, to retain some condensed mercury. Both of these conditions can be resolved with a thin metallic coating having appropriate electrical and thermal properties. With this in mind, tests were conducted to sputter deposit, using an ion source, a thin adherent film of Mo on both sides of the beam shield.

Prior to insertion in the vacuum facility the cleaning procedure similar to that for the $\mathrm{H}-\mathrm{I} 3$ steel was employed. An additional step of degassing with Freon was also performed before the cleaning with Liquinox $(B)$ solution. The beam shield was placed on a turntable on the bottom of the bell jar in port 2 of tank 4 at Lewis Research Center. The turntable rotated at a rate of approximately $2 \mathrm{rpm}$. - Each side of the beam shield was coated in a single operation. Other beam shield specimens were also mounted on the turntable in a conf iguration such that one specimen received the maximum shield coating thickness and the other the minimum. On the interjor surface of the beam shield a 600 to 2000 A-thick coating of pure Mo was deposited on the surface at a rate of $10 \mathrm{~A} / \mathrm{min}$. The shield was removed from the chamber and the exterior surface of the shield was coated with 2000 to $4000^{\circ} \AA$ of Mo by sputter deposition resulting from a $1070 \mathrm{eV}, 250 \mathrm{~mA}$ argon jon beam incident upon a Mo target.

Coating thickness measurements were made for both sides of the beam shield. The average thickness for the inside of the shield was $800 \AA$ of Mo and $2200 \AA$ of Mo for the outside of the shield. A measurement was made of the solar absorptivity and the thermal emittance on both the inside and the outside coated surfaces. These values are listed in Table IV along with the measurement of the surface resistance. These properties were those desired on the bean shield.

The coated beam shield. was subjected to acceleration tests up to $50 \mathrm{~g}$ 's. After the aceleration. tests, it was noted that the coating maintained its integrity indicating a conformal adherent coating. 


\section{Conçluding Remarks}

A $30 \mathrm{~cm}$ diameter argon ion source was used to sputter deposit adherent metallic films up to $8 \mu \mathrm{m}$ thick on $\mathrm{H}-13$ steel.' The adherence of the coatings. in most cases was greater than the upper limut of the adherence measuring device. The corners of thermal fatigue test specimen made of $\mathrm{H}-13$ steel were sputter deposited with metallic coatings one micron thick and than imnersed in liquid aluminum and cooled by water for 15,000 cycles to simulate operational environments. The results of these studies show that some materials do protect the $\mathrm{H}-13$ steel by reducing thermal fatigue and thereby increase die lifet ime.

A series of tests were performed to optimize conditions to.produce diamond-like films. Methane was introduced into the main discharge chamber of the $30 \mathrm{~cm}$ ion source and the proper ratio of $\mathrm{CH}_{4}$ to Ar necessary to generate a film on Si and quaity was determined. A dual beam ion source system, created by directing an $8 \mathrm{~cm}$ argon ion source beam (200-600 ev) at the substrates was also used to increase the mobility of the condensing atoms during film deposition which may have promise of increasing crystallivity. These films had carbon content similar to that of natural diamond with some of the properties of diamond.

The beam shield incorporated in the $8 \mathrm{~cm}$ diameter mercury ion thruster to be flight tested on the Shuttle-launched Air Force Space Test Program P80-1 satellite was coated using an ion source with an adherent coating of molybdenum. The molybdendum coating insured proper thermal and electrical properties, thus eliminating mercury condensation during eclipse operation and undesirable electrical-breakdown during thruster operation.

\section{References}

1. Vossen, J. L., and Kern, W., Thin Film Processes, Academic Press, 1978.

2. Mirtich, M. J., "Adherence of Ion Beam Sputter Deposited Metal Films on H-13 Steel," NASA TM 81585, 1980.

3. Sovey, J. S., "A 30-Cm Diameter Argon Iron Source," AIAA paper 76-1017, Nov. 1976.
4. Robinson, R. S., "Physical Processes in Directed Ion Beam Sputtering," Ph. D. Thesis, Colorado State University, Fort Collins, Colorado, March 1979. (NASA CR-159567.)

5. Benédyk, J. C., Moracz, D. J., and Wallance, J.F., "Thermal Fatigue Behavior of Die Materials for Aluminum Die Casting," Society of Die Casting Engineers International Die Casting Exposition and Congress, Sixth, $C$ leve land, $0 \mathrm{H}$, November $16-19 ; 1970$, SOCE paper no. 111 .

6. Holland, L., and 0Jha, S. M., "Infrared Transparent and Amorphous Carbon Grown Under Ion Impact in a Butane Plasma," Thrn Solld Films, Vol. 48,1978 , pp. L21-L23.

7. Berg, S., and Anderson, L. P., "Diamond-Like Carbon Fjlms Produced in a Butane Plasma," Thin Solid Fi]ms, Vol. 58, 1979, pp. 117-120.

8. Spencer, E. G., Schmidt, P. H., Joy, D. J., and Sansalone, F.J., "Ion-Beam-Deposited Polycrystalline Diamondlike Films," Applied Physics Letters, Vo1. 29, No. 2, July 15, 1976, pp. I18-120.

9. Arsenberg, S., and Chabot, R., "Ion Beam Deposition of Thin Films of Diamond7ike Carbon," Journal of Applied Physics, Vol. 42, no. 7, June 1971, pp. 2953-2958.

10. Weissmantel, C., Reisse, G., Erler, H. J., Henry, F., Bewilogua, K., Ebersbach, U., and Schurer, C., "Preparation of Hard Coatings by Ion Beam Methods," Thin Solid Films, Vol. 63, 1979 , pp. 315-325.

11. Angus, J., "Characterization of Diamond Like Films," NASA Contract NAS 3-22478, with Case Western Reserve University.

12. Marinow, M. and Dobrev, D.,."The Change in the Structure of Vacuum-Condensed Hexagonal ClosePacked Metal Films in I on Bombardment," Thin Solid Films, Vol. 42, 1977, pp. 265-268.

13. Power, J. L., "Planned Flight Test of a Mercury I on Auxiliary Propulsion System, I - Objectives, Systems Descriptions, and Mission Operations," NASA TM-78859, 1978. 
TABLE I. - SPUTTER DEPOSITION RATES FOR VARIOUS TARGET MATERIALS

[Ion energy, $1000 \mathrm{eV}$, ion current density at the target;, $1 \mathrm{~mA} / \mathrm{cm}^{2}$; target to substrate distance, $19 \mathrm{~cm}$, ion source to target, $19 \mathrm{~cm}$.

\begin{tabular}{|l|c|c|c|c|c|c|c|c|c|c|c|c|c|}
\hline $\begin{array}{c}\text { Target } \\
\text { material }\end{array}$ & $\mathrm{Ag}$ & $\mathrm{Au}$ & $\mathrm{Si}_{3} \mathrm{~N}_{4}$ & $\mathrm{Cr}_{3} \mathrm{C}_{2}$ & $\mathrm{Pt}$ & $\mathrm{Ni}$ & $\mathrm{Cr}$ & $\mathrm{A}_{1} \mathrm{~N}$ & $\mathrm{Co}$ & $\mathrm{Mo}$ & $W$ & $\mathrm{Z}_{r} \mathrm{O}_{2}$ & $\mathrm{Ta}_{5} \mathrm{Si}_{3}$ \\
\hline $\begin{array}{c}\text { Deposition } \\
\text { rate, A/min }\end{array}$ & 120 & 97 & 96 & 96 & 48 & 27 & 26 & 25 & 24 & 19 & 16 & 16 & 15 \\
\hline
\end{tabular}

TABLE II. - AOHERENCE OF MATERIALS ION BEAM SPUTTER

DEPOSITED ON H-13 STEEL

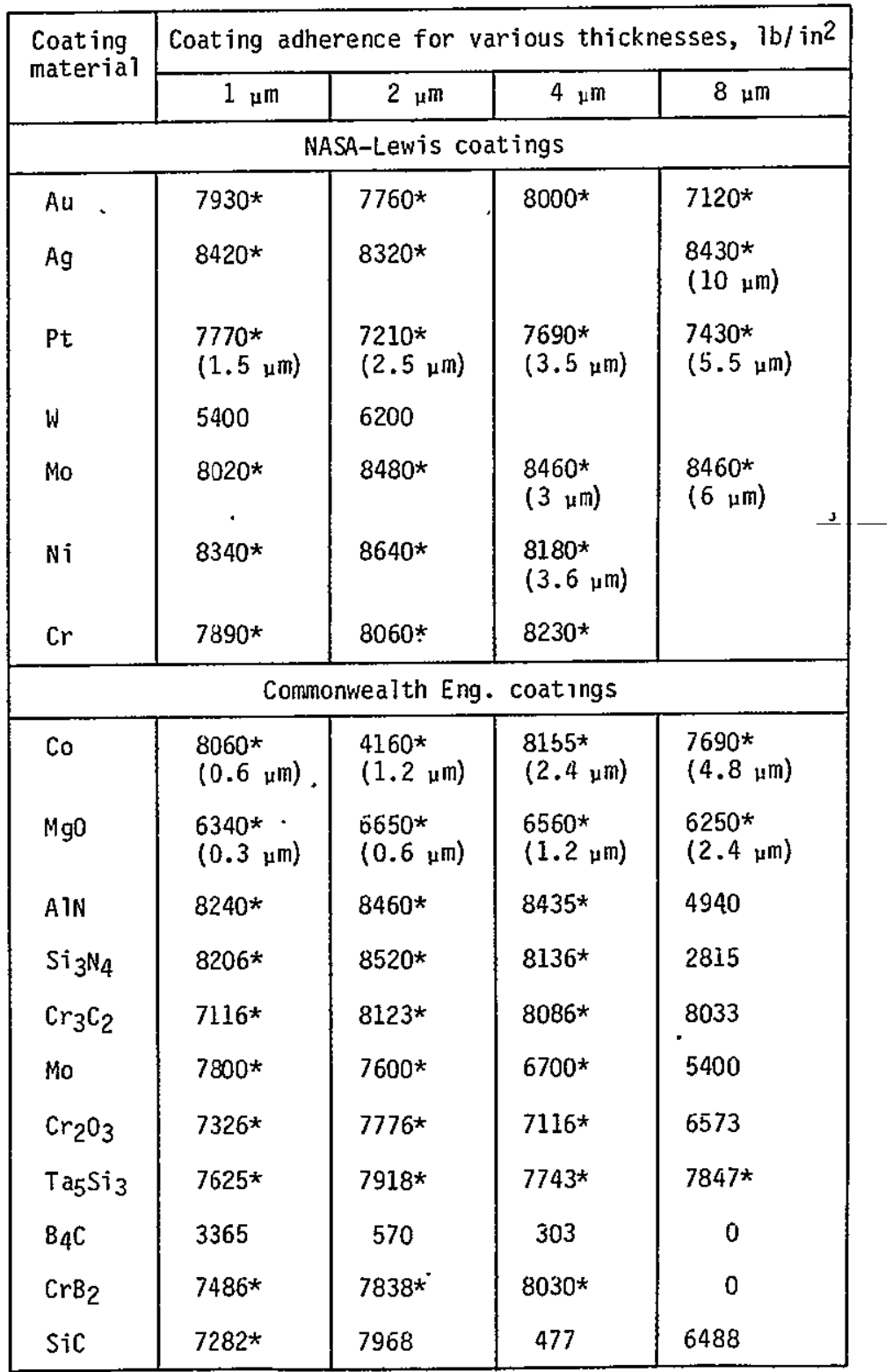

*Bond broke at epoxy-film interface. 
TABLE III. - THERMAL FATIGUE TEST RESULTS OF H-13 STEEL WITH VARIOUS ION DEPOSITED COATINGS

\begin{tabular}{|c|c|c|c|c|}
\hline \multicolumn{2}{|c|}{ Specımen description } & \multicolumn{2}{|c|}{$\begin{array}{c}\text { Maximum crack length, } \\
\mathrm{d}\left(\mu \times 10^{2}\right)\end{array}$} & $\begin{array}{l}\text { Crack area } \\
\Sigma \text { nd }^{2}\left(\mu^{2} \times 10^{6}\right)\end{array}$ \\
\hline R1 & $\begin{array}{l}\text { Control } \\
0.17_{\mu} \mathrm{Mo} / 1.0_{\mu} \mathrm{Pt} \\
.17_{\mu} \mathrm{W} / 1.0 \mu \mathrm{Pt} \\
1.0 \mu \mathrm{Pt}\end{array}$ & $\begin{array}{r}23 \\
31 \\
33 \\
.17\end{array}$ & · & $\begin{array}{r}101.7 \\
117.1 \\
140.6 \\
60.0\end{array}$ \\
\hline R2 & $\begin{array}{l}\text { Control } \\
1.0 \mu \mathrm{Pt} \\
1.0 \mu \mathrm{W}\end{array}$ & $\begin{array}{l}25 \\
20 \\
24\end{array}$ & & $\begin{array}{r}100.2 \\
58.1 \\
41.5\end{array}$ \\
\hline R4 & $\begin{array}{l}\text { Control } \\
1.0 \mu \mathrm{Si}_{3} \mathrm{~N}_{4} \\
1.0 \mu \mathrm{W} \\
1.0 \mu \mathrm{Pt}\end{array}$ & $\begin{array}{l}25 \\
23 \\
31 \\
11\end{array}$ & $\therefore$ & $\begin{array}{l}80.4 \\
59.2 \\
67.4 \\
36.6\end{array}$ \\
\hline 25 & $\begin{array}{l}\text { Control } \\
1.0 \mu \mathrm{AlN}^{2} \\
1.0 \mu \mathrm{Cr}_{3} \mathrm{C}_{2} \\
1.0 \mu \mathrm{Si}_{3} \mathrm{~N}_{4}\end{array}$ & $\begin{array}{r}39 \\
27 \\
28 \\
27 \\
\quad \quad 27\end{array}$ & & $\begin{array}{r}101.1 \\
100.2 \\
86.1 \\
66.2\end{array}$ \\
\hline R7 & $\begin{array}{l}\text { Control } \\
0.5_{\mu} W \\
1.0 \mu W \\
2.0 \mu W\end{array}$ & $\begin{array}{r}37 \\
38 \\
. \quad 27 \\
29\end{array}$ & & $\begin{array}{r}126.0 \\
171.0 \\
86.1 \\
74.2\end{array}$ \\
\hline \$2 & $\begin{array}{l}\text { Control } \\
1 . \mathrm{O}_{\mathrm{H}} \mathrm{Ta}_{5} \mathrm{Si}_{3} \\
1 . \mathrm{O}_{\mu} \mathrm{Mo} \\
1 . \mathrm{O}_{\mu} \mathrm{ZrO}_{2}\end{array}$ & $\begin{array}{l}25 \\
32 \\
15 \\
28\end{array}$ & . & $\begin{array}{l}65.2 \\
87.9 \\
29.7 \\
47.7\end{array}$ \\
\hline R3 & $\begin{array}{l}\text { Control } \\
1.0 \mu \mathrm{Co} \\
1.0 \mu \mathrm{Au} \\
1.0 \mu \mathrm{W}\end{array}$ & $\begin{array}{l}10 \\
10 \\
10 \\
2.5\end{array}$ & & $\begin{array}{r}15.4 \\
62.3 \\
58.3 \\
.27\end{array}$ \\
\hline R9 & $\begin{array}{l}\text { Control } \\
1.0_{\mu} \mathrm{Ag} / \mathrm{Cu} \\
1.0_{\mu} \mathrm{Pt} \\
1.0_{\mu} \mathrm{Ag}\end{array}$ & $\begin{array}{r}12 \\
10 \\
9 \\
16\end{array}$ & v & $\begin{array}{l}36.4 \\
20.1 \\
13.2 \\
77.0\end{array}$ \\
\hline
\end{tabular}

TABLE IV. - ELECTRICAL AND THERMAL PROPERTIES OF

- COATED FIBER GLASS BEAM SHIELD

\begin{tabular}{|c|c|c|c|c|}
\hline Surf ace & $\begin{array}{c}\text { Thyckness of } \\
\text { Mo coating, } \\
\mu \mathrm{m}\end{array}$ & $\alpha_{\mathrm{S}}$ & ET at $38^{\circ} \mathrm{C}$ & $\begin{array}{c}\text { Surface } \\
\text { resistance }\end{array}$ \\
\hline Interior & 0.0800 & 0.578 & 0.307 & $(120-350) \Omega$ \\
\hline Exterior & 0.2200 & 0.611 & 0.325 & $\left(230-950^{\circ}\right) \Omega$ \\
\hline
\end{tabular}




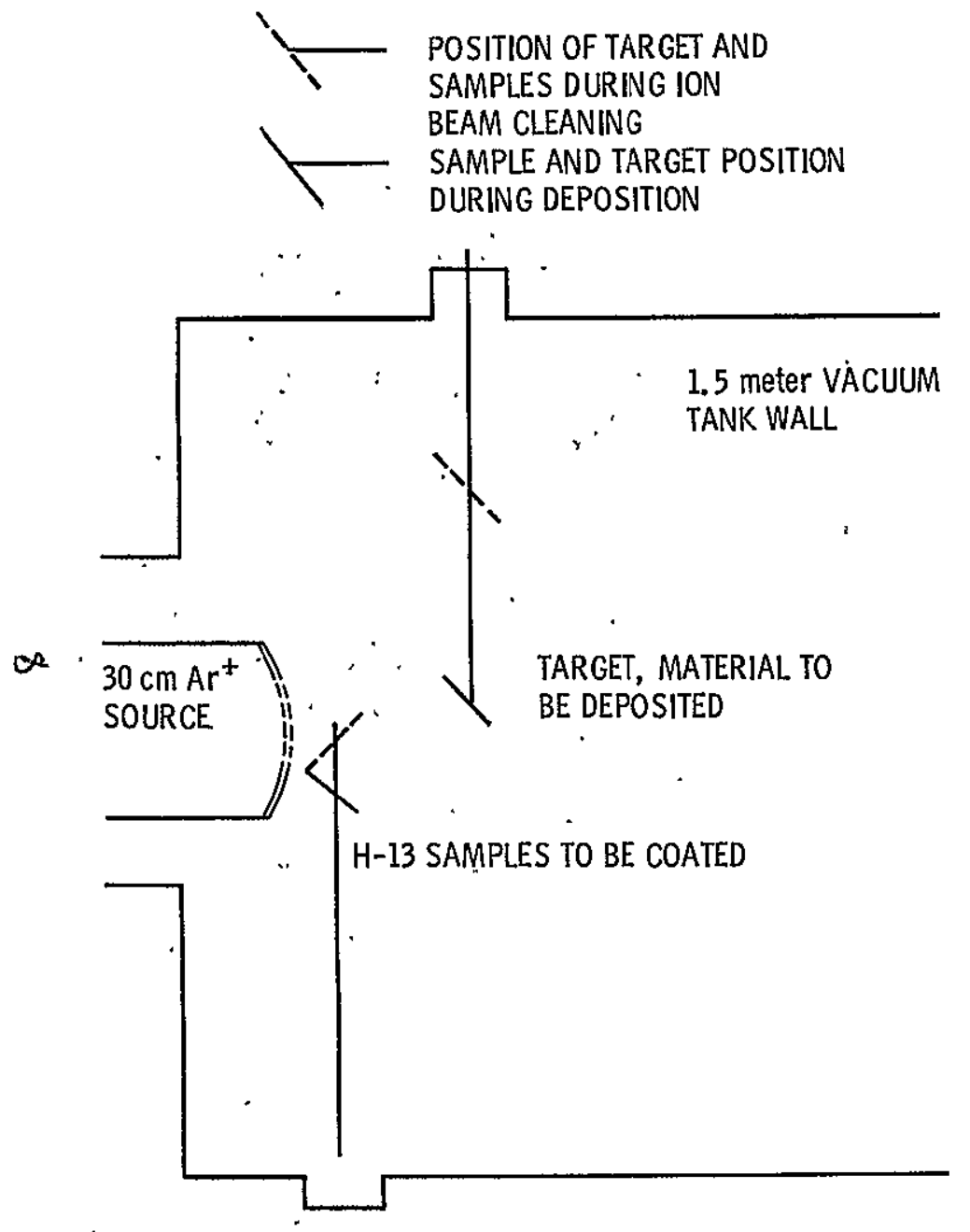

Figure 1. - Location of target-ion source and substrate at LeRC.

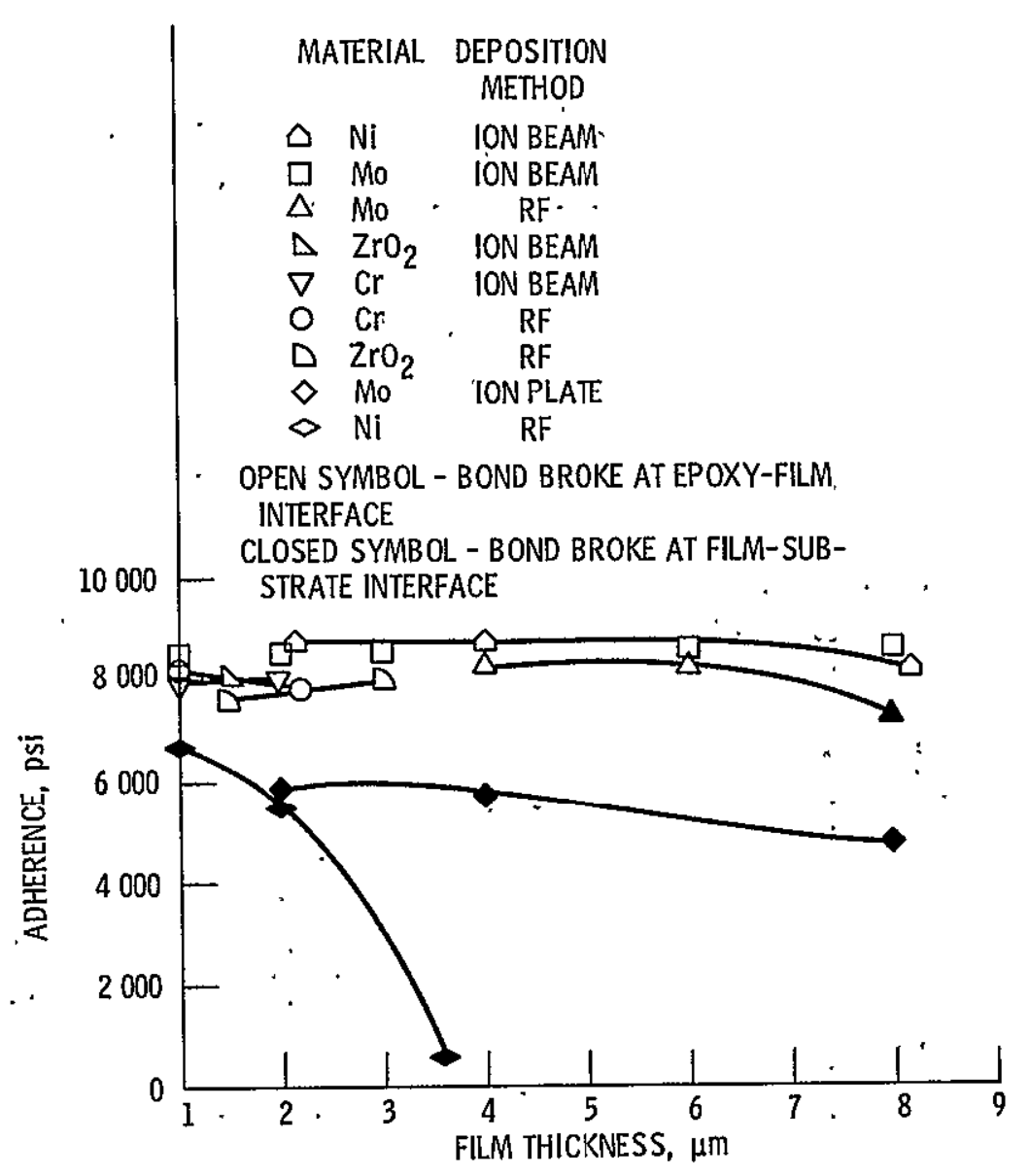

Figure 2 - Film adherence as a function of thickness for $\mathrm{Mo}, \mathrm{Cr}$, $\mathrm{Ni}$, and $\mathrm{ZrO}_{2}$ using different deposition systems. 


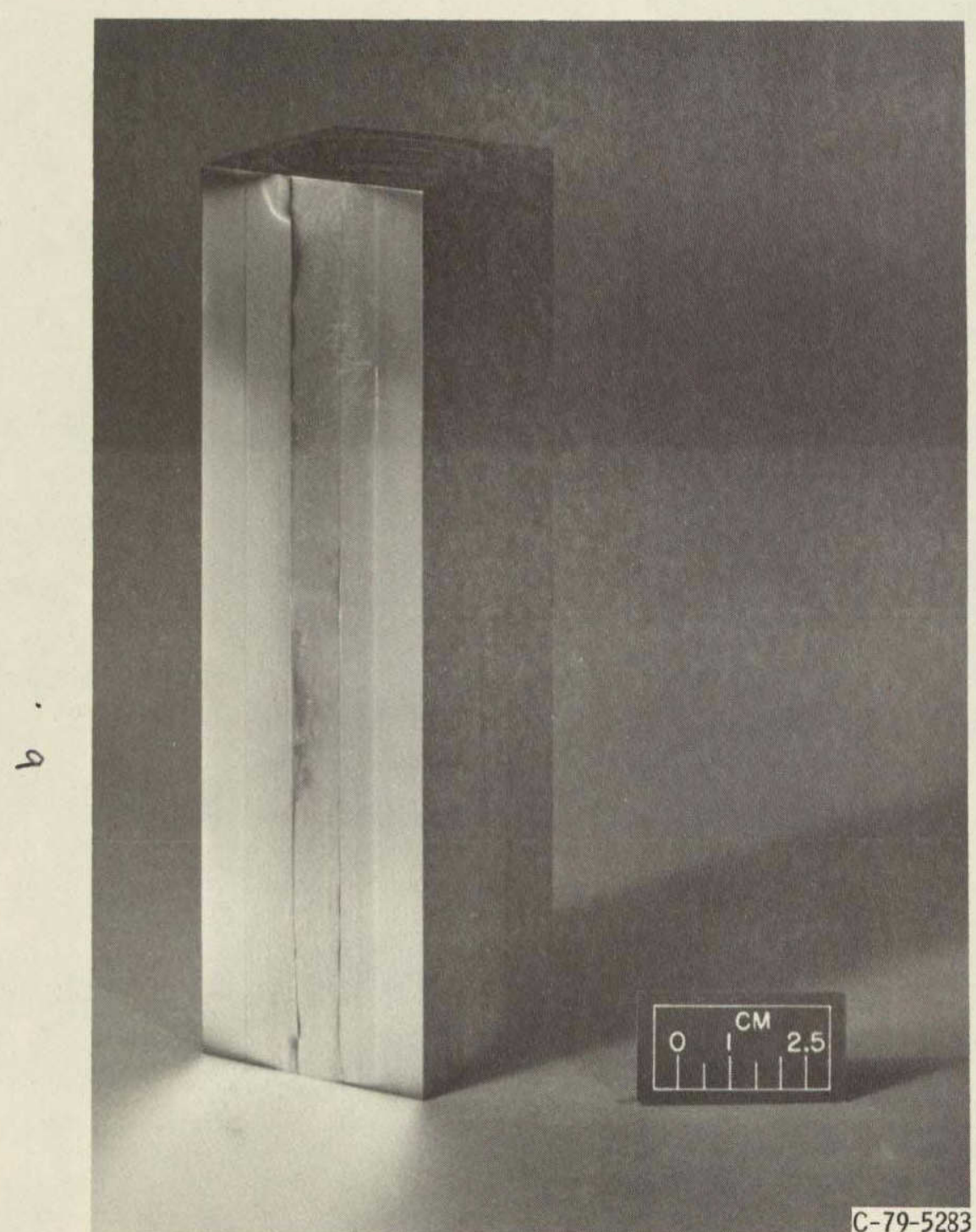

Figure 3. - A coated specimen, from left to right are cobalt, gold, and tungsten coatings.

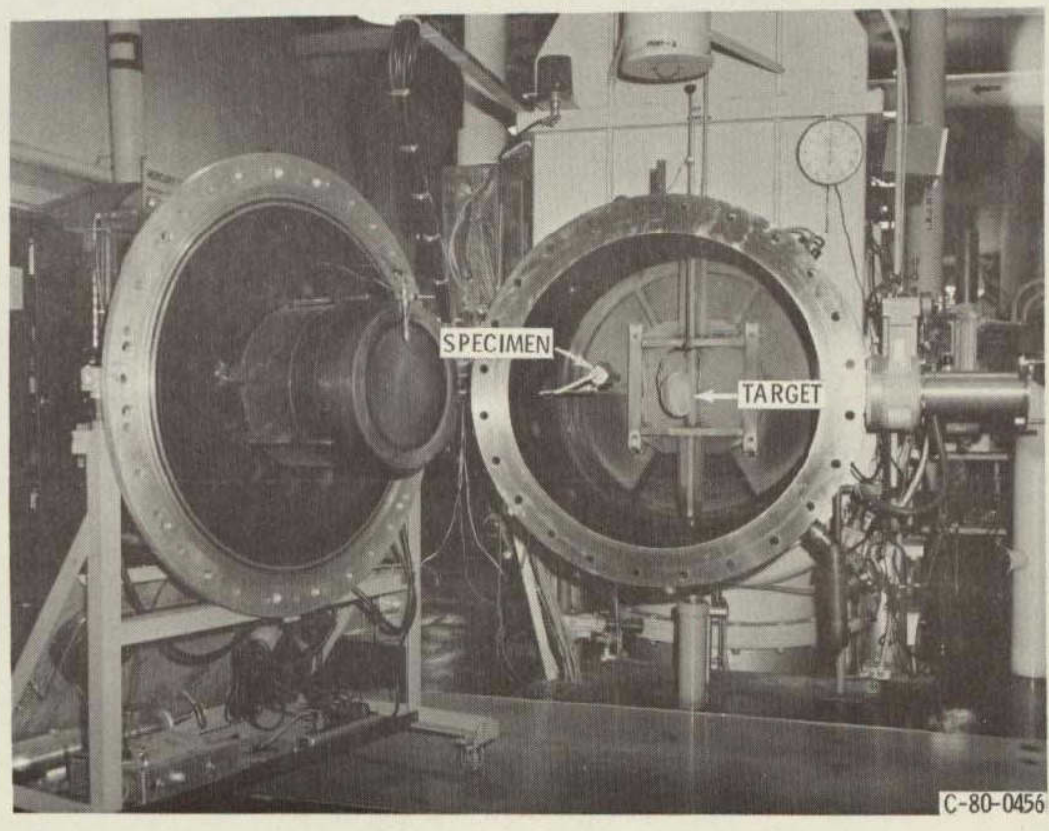

Figure 4. - Overview of bell jar, flange-ion source, target, test specimen, and fixturing.

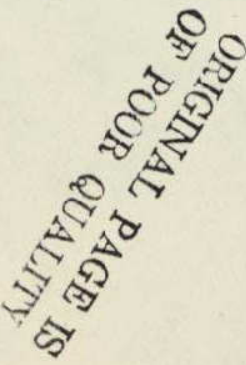




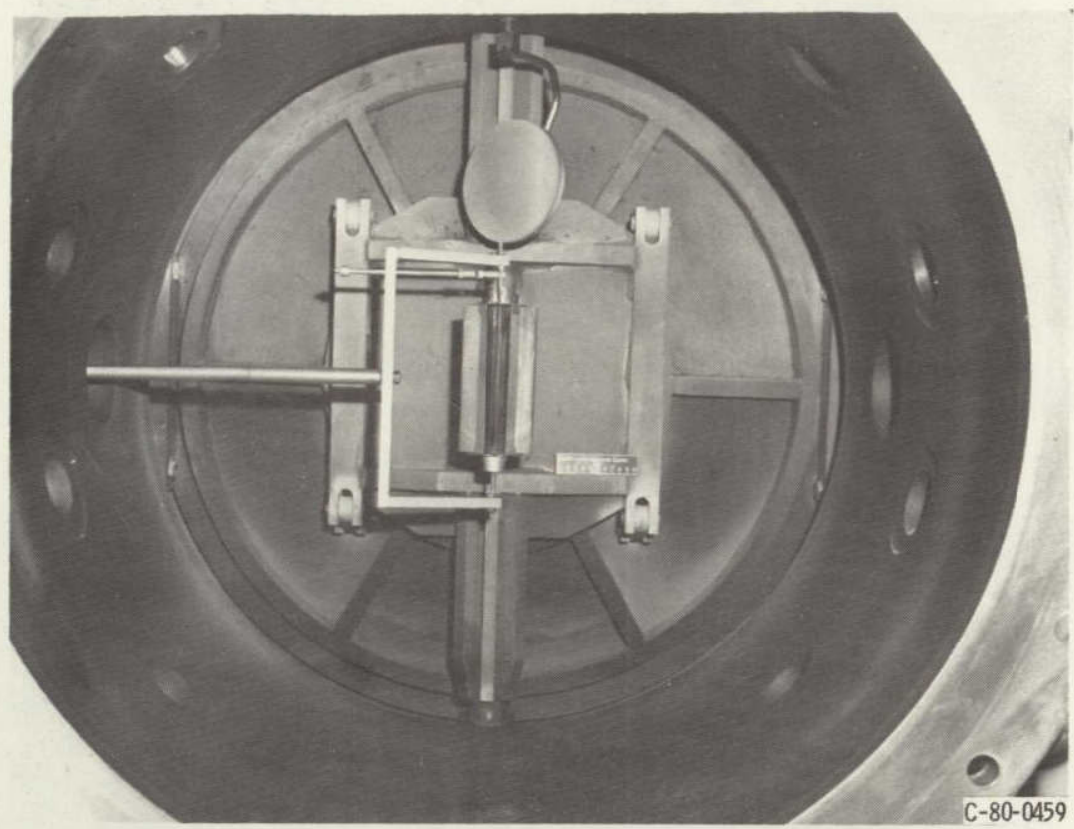

Figure 5. - Test specimen and target during cleaning of specimen.

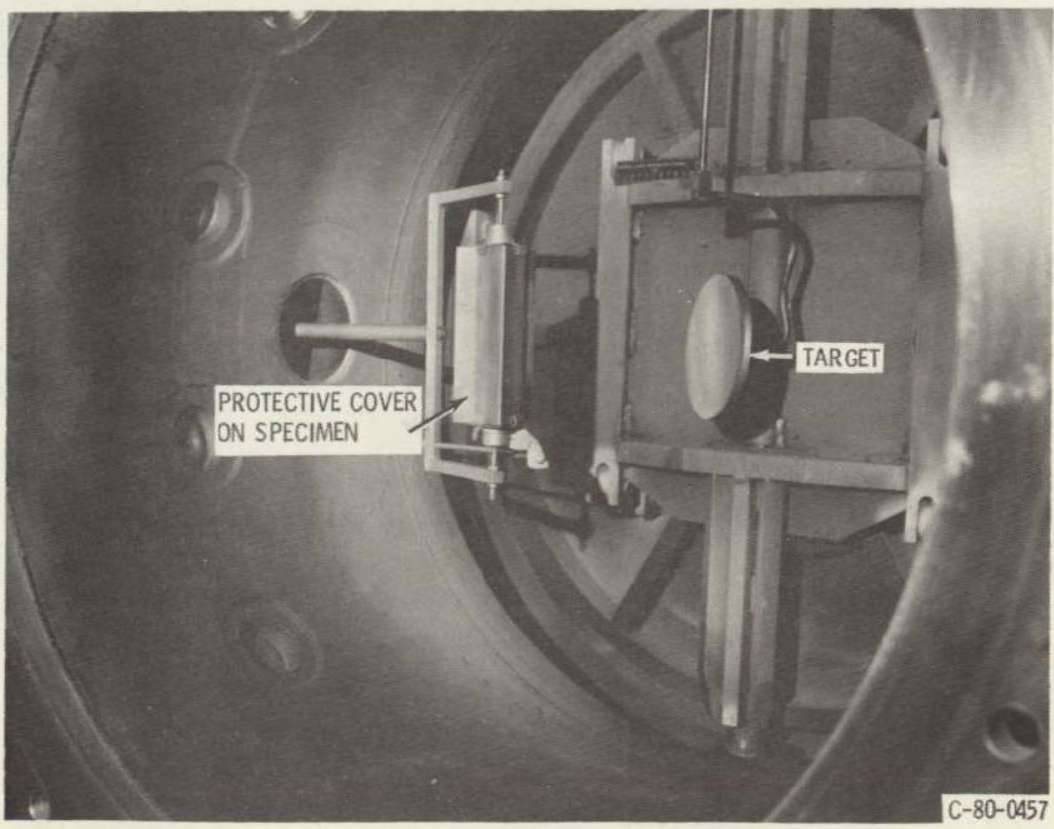

Figure 6. - Specimen position during coating. 


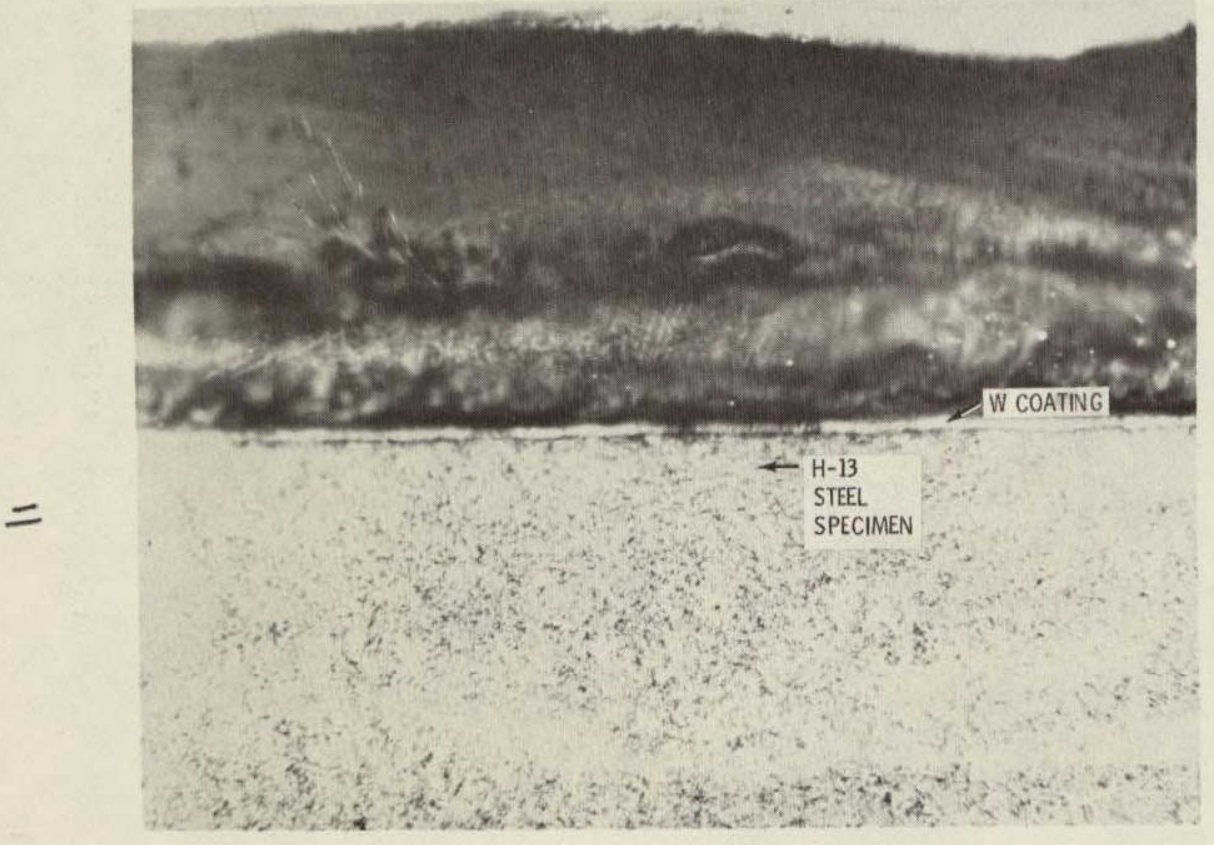

Figure 7. $-W$ coated specimen, the white line is the coating.

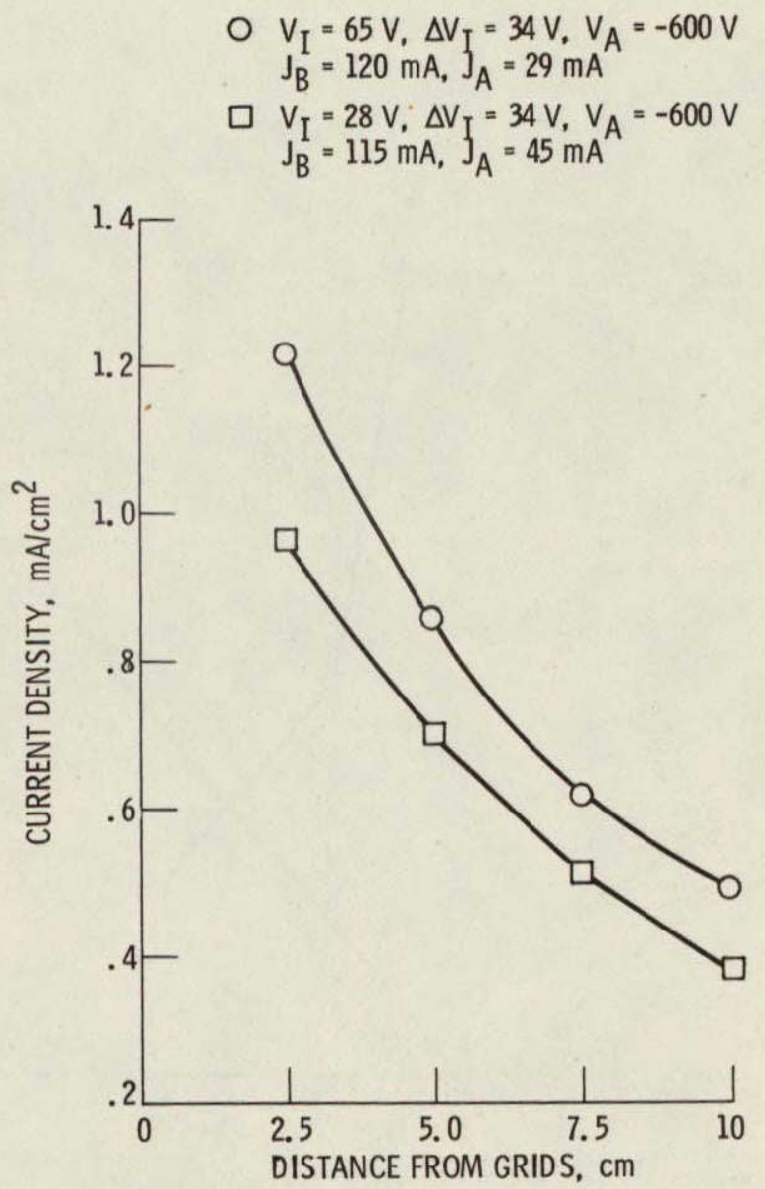

Figure 8. - Current density on centerline of $30-\mathrm{cm}$ ion for $\mathrm{CH}_{4} / \mathrm{Ar}=28 \%$. 


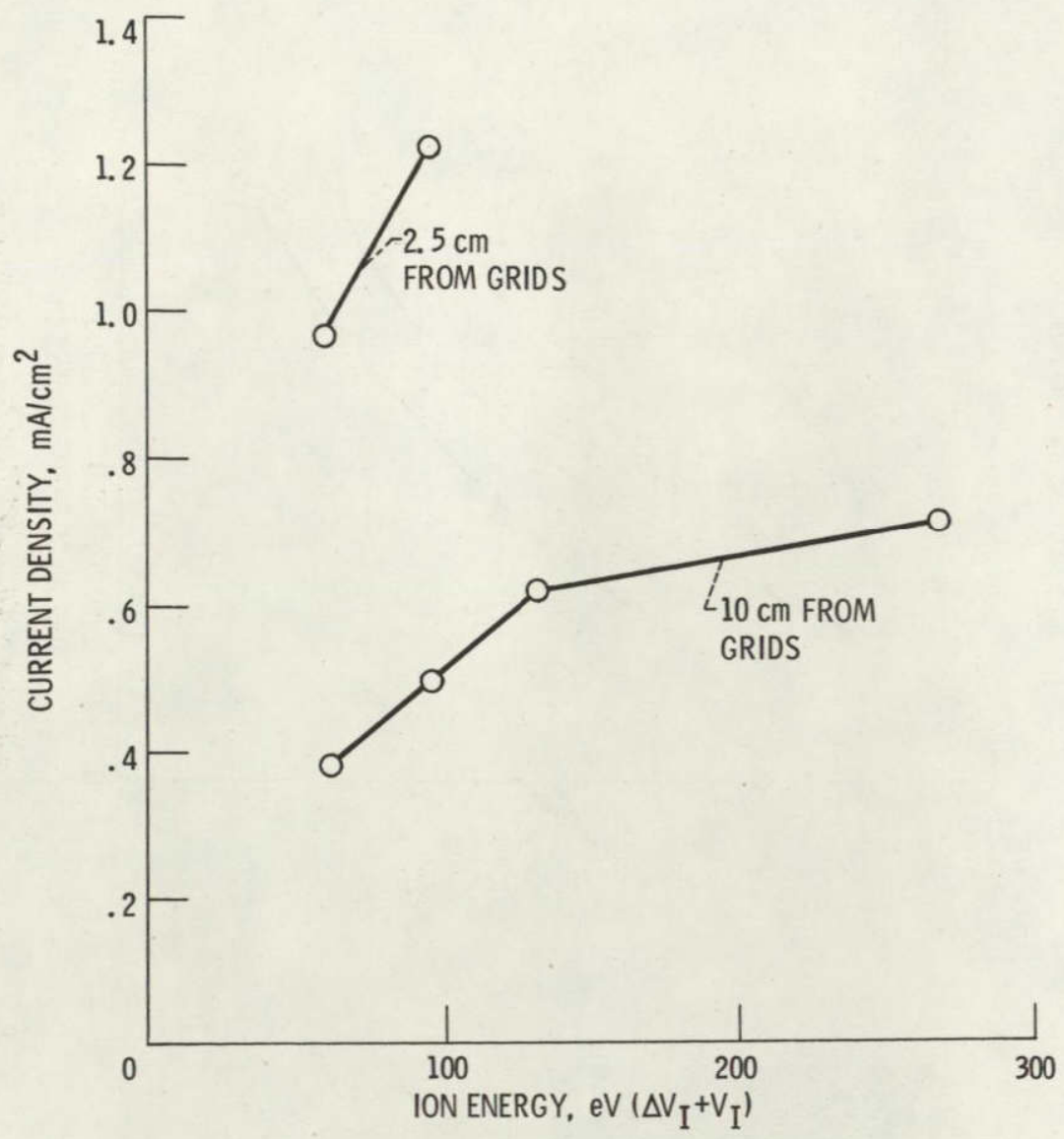

Figure 9. - Variation in current density with total ion energy for $\mathrm{CH}_{4} / \mathrm{Ar}=28 \%$ in a $30 \mathrm{~cm}$ ion source.

$$
\begin{aligned}
& \mathrm{V}_{\mathrm{I}}=200 \mathrm{~V}, \quad \Delta \mathrm{V}_{\mathrm{I}}=34 \mathrm{~V} \\
& \mathrm{~V}_{\mathrm{A}}=-600 \mathrm{~V}, \mathrm{~J}_{B}=118 \mathrm{~mA} \\
& \mathrm{~J}_{\mathrm{A}}=12 \mathrm{~mA}, \quad \mathrm{CH}_{4} / \mathrm{Ar}=28 \%
\end{aligned}
$$

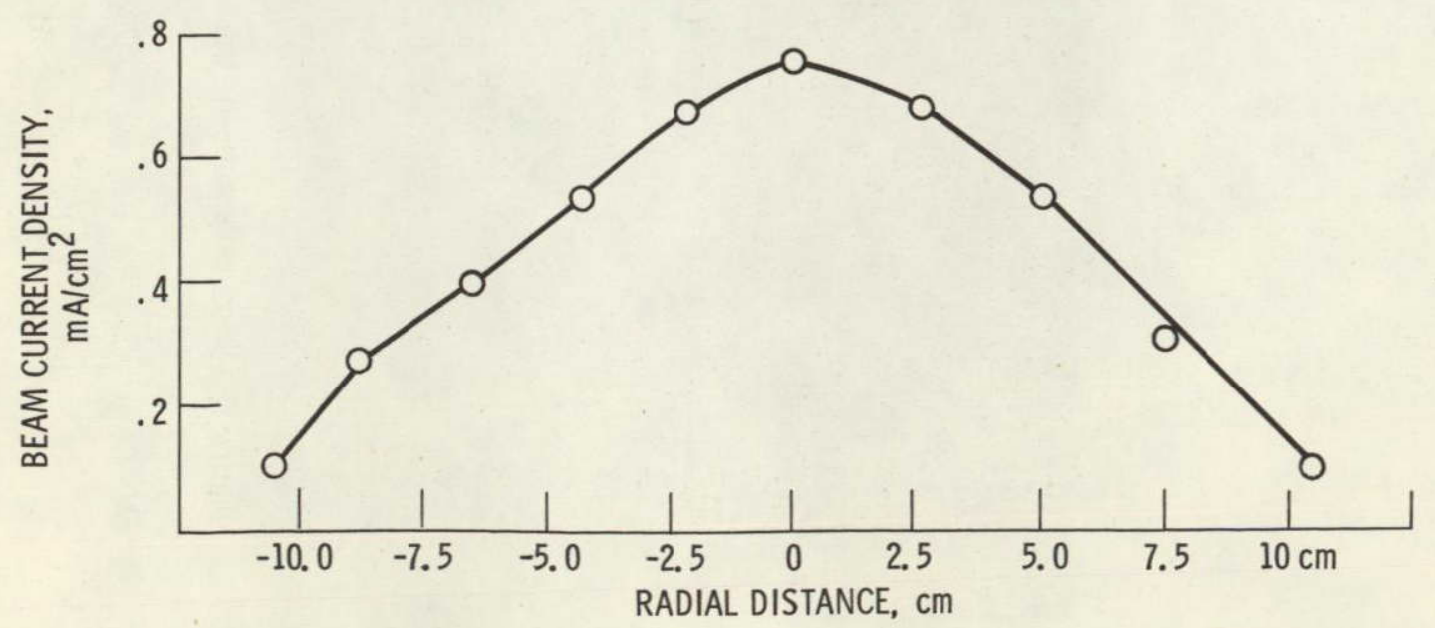

Figure 10. - Current density distribution $10 \mathrm{~cm}$ from grids. 


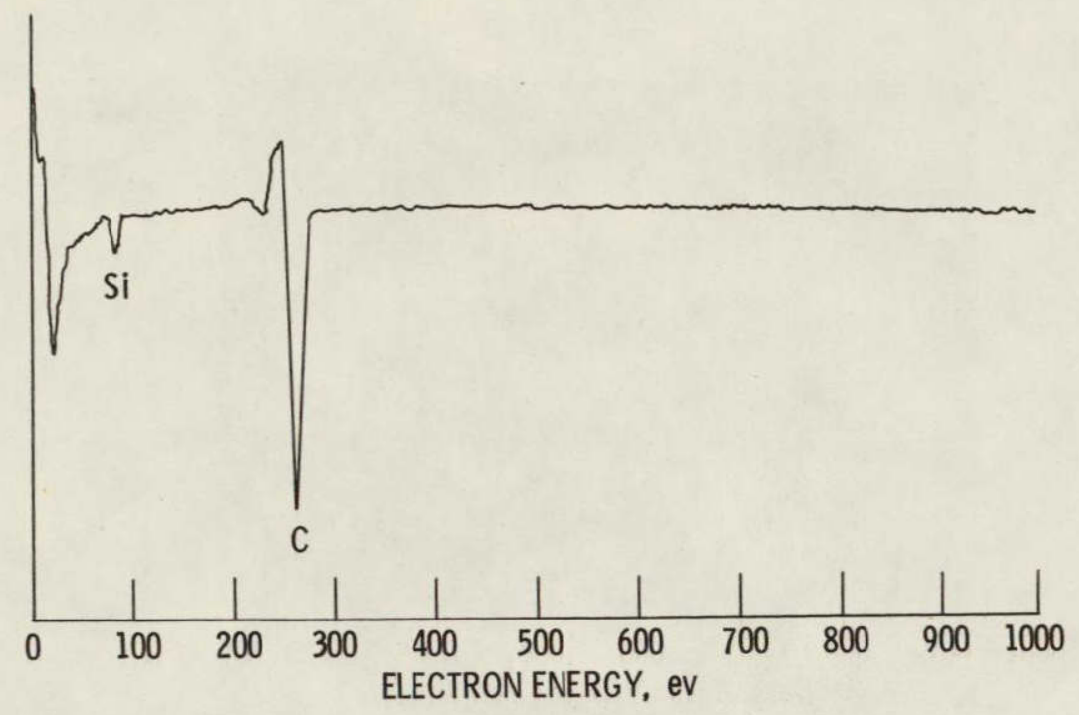

Figure 11. - SAM spectrum of diamond.

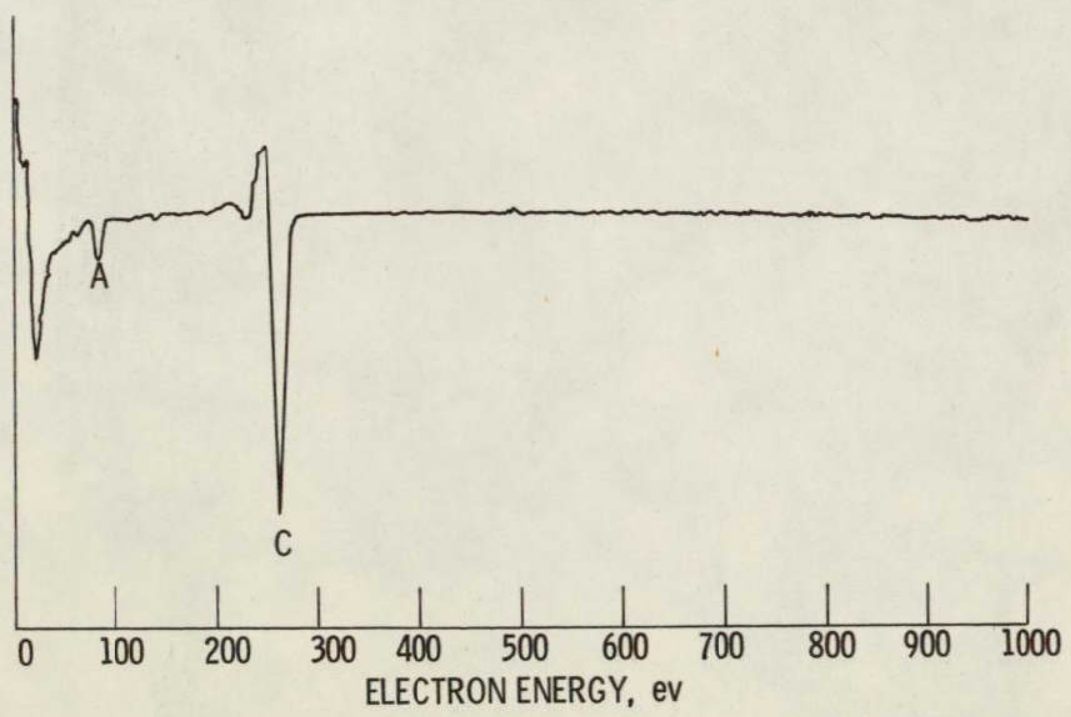

Figure 12. - SAM spectrum from nasa sample 9-30-80-2. 


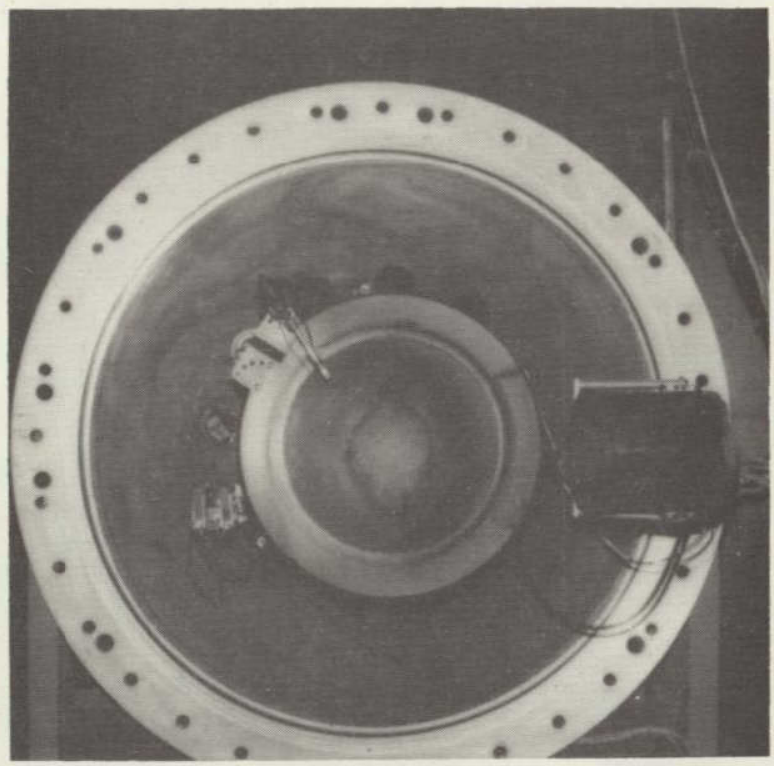

Figure 13. - Dual beam in source system.

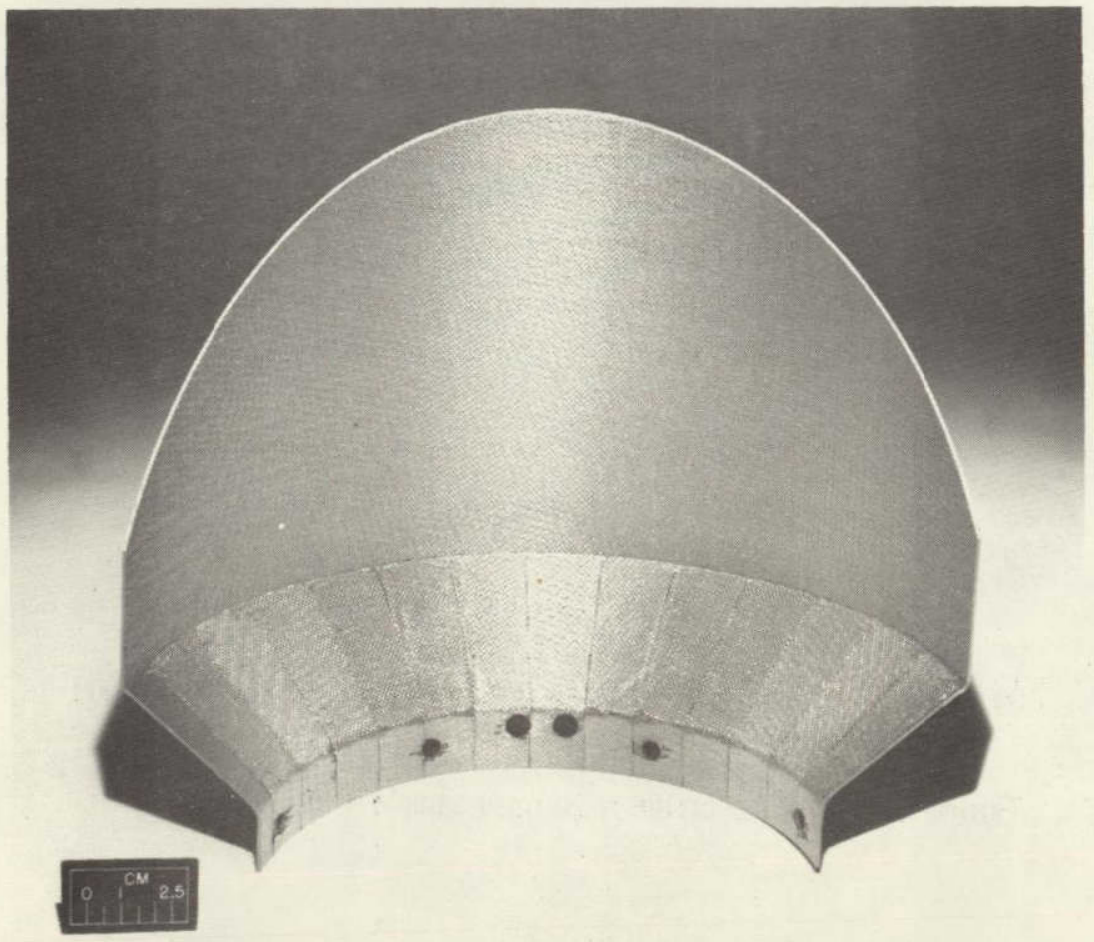

Figure 14. - Exterior surface view of $8 \mathrm{~cm}$ fiberglass beam shield coated with $2200 \AA$ Mo. C-78-521

$$
14
$$


National Aeronautics and Space Administration

Washington, D.C.

20546

Official Business

Penalty for Private Use, $\$ 300$
SPECIAL FOURTH CLASS MAIL BOOK
Postage and Fees Paid

Natıonal Aeronautics and Space Administration

NASA-451
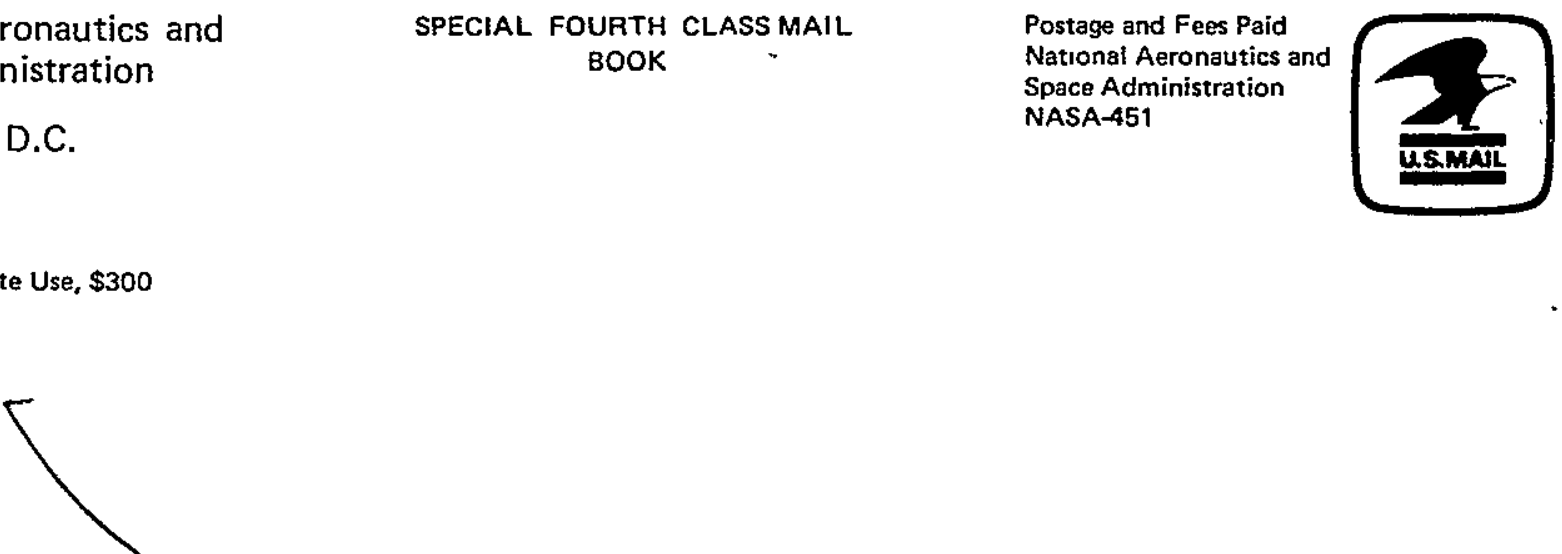

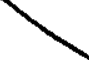
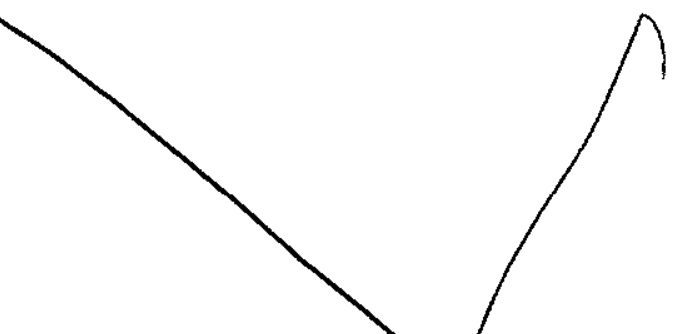